\title{
Manajemen Pendidikan Upaya Menghantarkan Pendidikan ke Arah yang Lebih Baik
}

\section{Hidayatul Mabrur}

$\begin{array}{lll}\text { Judul Buku } & : \begin{array}{l}\text { Menejemen Teori, Praktik, da } \\ \text { Pendidikan }\end{array} \\ \text { Penulis } & : \text { Prof. Dr. Husaini Usman, M.I } \\ \text { Tahun Terbit } & : \quad \text { Februari } 2006 \\ \text { Penerbit } & : \text { Bumi Aksara } \\ \text { Tebal } & : \quad \text { xxiii+532 Halaman }\end{array}$

\section{Pendahuluan}

Selamainikitatentunyasepakatuntukmengatakanbahwasegalasesuatu akan berjalan dengan baik jika pada awalnya hal tersebut telah termenej dengan baik pula. Ya, karena pada dasarnya menejemen merupakan sebuah konsep yang dijadikan landasan dalam pelaksanaan sesuatu pekerjaan agar menuju kepada suatu gerbang yang lebih baik dan terorganisir. Begitu pula halnya dalam dunia pendidikan. Telah terformulasikan bahwa sebuah pendidikan yang bermutu tentunya pendidikan yang berawal dari landasan menejemen yang terencana dan terorganisir pula. Maka

Lahir di Pontianak 18 Agustus 1989. Mahasiswa Program Studi Pendidikan Agama Islam (Angkatan 2007) FIAI UII sekaligus santri Pondok Pesantren UII. Aktif dilembaga pers mahasiswa Pilar Demokrasi FIAI UII. Ketua Forum Lingkar Diskusi Tarbiyah [FLDT] HMJ Tarbiyah 2008-2009.

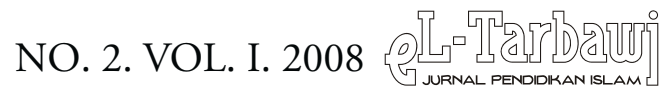


tak heran hingga saat ini banyak dari pakar pendidikan selalu mencoba untuk memberikan konstribusi dalam menggagas pemikirannya tentang bagaimana merumuskan menejerial kependidikan agar melahirkan output yang berkualitas. Apalagi pada era global yang semakin terbuka seperti saat ini, dimana segalanya dituntut untut bersikap dan bertindak secara profesional hal ini pulalah yang menuntut kita sebagai kaum akedemisi untuk bertindak secara bijaksana dalam menguasai berbagai disiplin dan menejemen ilmu.

Buku yang sedang kami resensi ini, merupakan hasil karya dari Prof. Dr. Husaini Usman, M.Pd., M.T yang berjudul, Menejemen Teori, Praktik, dan Riset Pendidikan. Karya ini merupakan sutu upaya manifestasi dari Prof. Dr. Husaini Usman, M.Pd., M.T dalam upaya memperkaya khasanah keilmuan pada dunia menejemen khususnya menejemen pendidikan. Sebagai alumnus magister administrasi pendidikan yang juga berkecimpung dalam praktisi dunia pendidikan, Ia telah mencoba mememaparkan pembahasan yang menditail dan tertata secara runtun tentang menejemen secara umumnya dan implementasinya dalam menejemen pendidikan secara khusus. Buku ini ia susun dengan maksud agar dapat dikonsumsi dan digunakan oleh masyarakat luas yang berminat menambah wawasan dibidang ilmu yang bersifat universal. Universal dalam artian dikarenakan pada dasarnya menejemen dapat diterapkan pada setiap ranah keilmuan dan kehidupan, termasuk pendidikan. Maka buku ini cukup bisa dijadikan acuan dalam menejemen kependidikan, teori dan konsep menejemen beserta aplikasinya dalam dunia pendidikan cukup banyak disinggung pada bab-bab di dalamnya.

\section{B. Diperkaya Dengan Teori dan Pengalaman Riset}

Secara teoritis, buku ini membahas teori dan konsep menejemen yang bersifat umum yang kemudian teori dan konsep tersebut secara praktis diterapkan dalam bidang pendidikan. Disamping itu dibahas pula mengenai berbagai teori dan konsep menejemen beserta aplikasinya dalam dunia pendidikan, yaitu berupa praktik dan riset pendidikan. Praktik dan hasil riset yang ditulis dalam buku ini sengaja dipilih hanya pengalaman praktik dan hasil riset yang sudah dimuat jurnal terakreditasi saja, karena hanya karya ilmiyah yang bermutu yang berhasil dimuat pada jurnal terakreditasi 
tersebut. Hampir $99 \%$ pengalaman praktik dan hasil penelitian yang ditulis dibuku ini berasal dari bumi Indonesia. Tujuan adalah agar penerapan menejemen pendidikan kita tidak terserabut dari akar sosial budaya Indonesia.

Disisi lain, tujuan dicantumkannya beberapa hasil dan pengalaman riset dalam buku ini bertujuan untuk memberikan inspirasi kepada pembaca agar dapat membantu dalam penigkatan mutu yang berkenaan dengan permasalahan menejemen pendidikan ala Indonesia. Sebagai salah satu contoh pada akhir bab awal penulis memaparkan hasil penelitian dari Sugeng Bayu Wahyono (1997:11-12) yang menemukan bahwa birokrasi pendidikan ternyata mengidap patologis (penyakit) yang tingkat keparahannya cukup memprihatinkan. Dalam penelitian ini peneliti menemukan empat jenis penyakit yang terdiagnosa, yang pada kesimpulannya hal ini akan berimplikasi pada rendahnya profesionalisme guru SD dalam aktivitas mengajarnya. Maka, dengan dicantumkannya beberapa hasil riset tadi tentunya telah menjadi sebuah upaya tersendiri bagi penulis sajikan guna memeperkaya isi buku tersebut sebagai sumber inspirasi baru bagi pembaca dan sekaligus menjadikan nilai plus bagi buku ini terhadap buku-buku yang lain.

\section{Sisitematika Penulisan}

Sistematika dalam penulisan buku ini dijabarkan dalam beberap bab pokok dan dipertegas dengan beberapa sub-sub bab pendukung, yang dikemas dalam 14 bagian bab.

Bab Pertama dan kedua, membahas tentang konsep dasar administrasi dan menejemen, didalamnya penulis memulai dengan memaparkan beberapa difinisi k atau kunci (key word) dari beberapa prihal subtantif yang dikupas dalam buku ini, seperti pengertian dari administrasi, menejemen, pendidikan, tujuan dan manfaat menejemen pendidikan, maupun ruang lingkup menejemen pendidikan. Kemudian bab kedua, Menjelaskan Perkembangan Teori Menejemen, didalamnya Teori menejemen klasik, beberapa pendekatan (Approach) seperti pendekatan teori prilaku, pendekatan kuantitatif, pendekatan sistem, pendekatan kontingensi pendektan hubungan manusia baru hingga pada akhirnya dikemukan 
praktik menejemen dan hasil riset.

Bab ketiga dan keempat, membahas tentang perencanan dan pengorganisasian, didalamnyamengupastentang filsfatperencanaan, tujuan, manfaat, pengertian, sejarah, ruang lingkup, teori perencanaan hingga ke teknik-teknik perencanaan. Kemudian bab empat, mulai memasuki pada ranah pembahasan pengorganisasian, didalamnya membahas tentang pengertian, tujuan, manfaat, tipe, pengembangan, efektivitas organisasi hingga keperubahan organisasi dan hasil riset.

Bab lima dan enam, membahas tentang motivasi, kepemimipin dan kekuasaan, didalamnya berusaha mengupas bagaimana manfaat teori, motivasi dan motif, teknik serta praktik dan hasil riset motivasi. Dalam bab enam membahas tentang kepemimpinan dan kekuasaan, yang didalamnya diperdalam tentang manfaat kepemimipinan, pengertian kepemimpinan, macam kepemimpinan, krangka prespektif kepemimipinan, konsep kepemimpinan dan kekuasaan serta praktik kepemimpinan pendidikan dan ditutup dengan hasil pengalaman riset.

Bab tujuh dan delapan membahas tentang pengambilan keputusan dan pemecahan masalah dan komunikasi, didalamnya membahas tentang pengertian, model pengambilan keputusan, tipe keputusan menejerial, metode keputusan, perbedaan pengambilan keputusan bersama kelompok dengan keputusan kelompok, keputusan diputuskan sendiri, pemecahan masalah, serta prakik pengambilan keputusan. Bagian kedelapan membahas tentang komunikasi yang didalamnya membahas tentang, tujuan dan manfaat komunikasi, pengertian, proses, interaksi leader atau menejer, jalur komunikasi, bentuk, prinsip, hambatan-hambaan komunikasi, kemudian dijelaskan juga didalamnya teknik berkomunikasi secar efekif, penggunaan komunikasi oral dan tertulis serta praktik komunikasi dan hasil riset.

Bab sembilan dan sepuluh membahas tentang tujuan dan manfaat koordinasi, pengerian koordinasi, kooprasi dan sinerji, macam koordinasi, pendekatan koordinasi, jenis koordinasi, prinsip koordinasi, karakteristik koordinasi yang efektif, koordinasi sumber daya pendidikan hingga praktik koordinasi dan hasil riset. Kemudian pada bab sepuluh dilanjutkan pada pembahasan negoisasi dan konflik yang didalamnya membahas tentang pengertian negoisasi, manfaat negoisasi, macam negoisasi, serta teknik 
negoisasi, kemudian dilanjutkan dengan pembahasan tentang konflik, konflik dalam organisasi, bentuk konflik, penyebab konflik, setrategi mengatasi konflik, taktik mengurangi konflik, hasil konflik, model untuk mengatasi konflik hingga pembahasan hubungan konflik dengan efektivitas organisasi dan prakik negoisasi dan konflik.

Bab sebelas dan duabelas membahas tentang pengendalian dan menejemen mutu terhadap pendidikan, didalamnya dimulai dengan pembahasan tentang tujuan pengawasan dan pengendalian yang selanjutnya kami singkat menjadi Wasdal, manfaat wasdal, pengertian wasdal, proses wasdal, bentuk pengawasan, perosedur wasdal, ruang lingkup pengendalian, pengawasan sekolah, kemudian dibahas juga mengena difinisi, manfaat, pesan dan karakteristik mutu, hierarki mutu perkembangan mutu serta teknik, dan pengawasan untuk peningkatan mutu. Kemudian pada bab dua belas membahas tentang menejemen mutu terpadu pendidikan (MMTP), yang didalamnya membahas tentang pengertian MMTP, perbedaan MMTP dengan menejemen lainnya, prinsip dan komponen MMTP, efektifitas kerja komponen MMTP, kepemimpinan MMTP, Organisasi MMTP, perbedaan organisasi mutu dengan organisasi biasa, budaya MMTP, langkah-langkah MMTP, kemudian juga membahas tentang kerangka paradigma menejer pendidikan, hambatan penerapan MMTP, faktor sukses MMTP, asesmen penerapan MMTP, hingga pemaparantentang praktik MMTP dan hasil riset.

Kemudian pada bagian akhir, yakni pada bab tigabelas dan empat belas membahas menejemen penigkatan mutu berbasis sekolah dan menejemen sekolah, yang didalamnya membahas tentang bagaimana konsep menejemen berbasis sekolah (MBS), praktik MPMBS. Kemudian pada bab terakhir membahas membahas tentang menejemen sekolah didalamnya membahas tentang standar pelayanan sekolah (SPM) dan pedoman administrasi sekolah.

\section{Urgensitas Buku ini Untuk Dikonsumsi Bagi Para Praktisi dan Calon Pendidik}

Buku ini dilihat dari isi pembahasannya sangatlah menditail, halamannya berjumlah 532 halaman yang diambil dari berbagai referensi 
yang jumlah referensinya jika dikalkulasikan mencapai angka ratusan baik dari buku maupun sumber-sember lainnya. Maka tidaklah berlebihan jika penulis mengatakan bahwa buku ini sagat relevan untuk dijadikan referensi dalam bidang ilmu menejemen maupun menejemen pendidikan. Karena didalamnya, penulis telah memaparkan segala sesuatu yang berkenaan dengan menejemen ataupun hal-hal yag berkaitan dengan itu. Maka menurut kami, buku ini layak untuk dikonsumsi oleh segenap steak holder yaitu praktisi pendidikan, pengamat pendidikan maupun bagi calon guru sebagai tulang punggung yang akan segera berkecimpung dalam dunia pendidikan.

\section{E. Kesimpulan}

Buku hasil karya Prof. Dr. Husaini Usman, M.Pd., M.T ini, benarbenar telah memberikan referensi baru dalam khasanah keilmuan tentang mejemen pendidikan maupun yang berkenaan dengan itu, dalam bukunya, ia telah berusaha menyajikan pembahasan tentang Menejemen teori, praktik dan berbagai hasil riset yang ia kemas dalam empat belas bab secara runtun dan tersusun. Didalam buku ini, ada cirikhas tersendiri jika dibandingkan dengan buku-buku lain yang membahas tentang pembahasan serupa, yakni dimana didalamnya, penulis berusaha memperkaya dengan memaparkan beberapa hasil riset yang cukup bisa dijadikan sandaran bagi steak holder pendidikan.

Buku ini sangatlah relevan untuk dikonsumsi bagi para pengamat pendidikan, peraktisi pendidikan, pendidik, maupun masyarakat luas yang berminat menambah wawasan dibidang ilmu yang berkaitan dengan menejemen dan menejemen pendidikan. Buku ini akan semakin menjadi bermanfaat adanya, jika ada upaya dari pembaca untuk mengimplementasikannya dalam didalam bidang yang sedang ia tekuni. Karena bagaimanapun juga, kayu akan tetap menjadi kayu jika tak seorangpun yang mau merubahnya menjadi meja. 